\title{
Nebulized rhDNase therapy in newborn infants with atelectasis
}

\author{
Atelektazili yenidoğan bebeklerde nebülize rhDNaz tedavisi
}

\author{
Fatma Duksal*, Ömer Cevit", Ahmet Sami Güven**, Melih Timucin Doğan**, Betül Aslaner* \\ ${ }^{*}$ Cumhuriyet Üniversitesi, Tıp Fakültesi, Pediatri AD, Pediyatrik Alerji ve İmmünoloji BD, Sivas \\ ${ }^{* *}$ Cumhuriyet Üniversitesi, Tıp Fakültesi, Pediyatri AD, Sivas
}

\begin{abstract}
Purpose:To see the efficacy in atelectasis and clinical effectiveness of rhDNase in newborns unresponsive to conventional therapy.

Material and methods: Eight newborns (7 premature) with atelectasis in the lungs were evaluated retrospectively. All patients were given rhDNase $2.5 \mathrm{mg}$ twice daily with nebulizer for up to 3 days after conventional therapies. Results:The birth weight and gestational age of the patients ranged respectively from $500 \mathrm{~g}$ to $3000 \mathrm{~g}$ and 25 weeks to 41 weeks. When atelectasis developed, six of eight patients were mechanically ventilated. Infants received a dosage of $2.5 \mathrm{mg}$ rhDNase every 12 hours with nebulizer for 3 days. Six of 8 patients showed almost complete improvement after the rhDNase treatment. One patient who did not respond to the treatment had an underlying "hypoxic ischemic encephalopathy" and complicated pneumonia. This patient died during the follow up. The other patient gave partial response to treatment. Of 6 mechanically ventilated patients 3 patients extubated in 3 days, one patient extubated after 9 days and two patients could not be extubated. Atelectasis relapsed in 6 patients. After second 3-day course of treatment by a nebulizer, recovery was seen in 3 days. There was no side effect due to rhDNase treatment.

Conclusion:We suggest that rhDNase may be administered as an alternative treatment to the newborn infants with atelectasis in their lung. Especially, if there was no underlying disease, and if they did not respond to conventional treatment for atelectasis. More studies should be done with larger study groups.
\end{abstract}

Pam Med J 2014;7(2):113-118

Key words: Atelectasis, mechanical ventilaton, newborn, rhDNase.

\section{Özet}

Amaç: Geleneksel tedaviye yanıt vermeyen yenidoğanlarda rhDNaz'ın klinik olarak ve atelektazideki etkinliğini görmektir.

Gereç ve yöntem: Akciğerlerinde atelektazi olan 8 yenidoğan (7 prematüre) retrospektif olarak değerlendirilmiştir. Tüm hastalara geleneksel tedaviden sonra 3 gün boyunca günde $2 \mathrm{kez}$ olmak üzere $2,5 \mathrm{mg}$ dozunda rhDNaz nebülizatör ile verilmiştir.

Bulgular: Hastaların doğum kiloları ve doğum haftaları sırasıyla 500 gr-3000 gr ve 25 hafta-41 hafta arasındaydı. Atelektazi geliştiği sırada hastaların altısı mekanik ventilatördeydi. Bebekler 3 gün boyunca 2.5 mg dozunda rhDNaz, 12 saatte bir nebülizatör ile almışlardır. Sekiz hastanın altısı rhDNaz tedavisi sonrası tamamen düzelmiştir. Tedaviye yanıt vermeyen 1 hastanın altta yatan "hipoksik iskemik ensefalopati" ve komplike pnömoni hastalığı mevcuttu. Bu hasta takip sırasında kaybedilmiştir. Diğer hasta tedaviye kısmi yanıt vermiştir. Mekanik ventilasyonda olan 6 hastadan 3'ü 3 gün içerisinde, 1'i 9 gün sonra ekstübe edilmiştir. İki hasta ekstübe edilememiştir. Altı hastada atelektazi tekrarlamıştır. Üç günlük 2. kür nebülizatör ile tedaviden sonra 3 gün içerisinde düzelme görülmüştür. rhDNaz tedavisine bağlı herhangi bir yan etki oluşmamıştır.

Sonuç: rhDNaz, akciğerlerinde atelektazi olan yenidoğan bebeklerde alternatif tedavi olarak uygulanabilir. Özellikle altta yatan herhangi bir hastalığı olmayanlara ve atelektazi için geleneksel tedaviye yanıt vermeyenlere önerilebilir. Daha fazla sayıda çalışma grubuyla çalışmalara intiyaç vardır.

Pam Tip Derg 2014;7(2):113-118

Anahtar sözcükler: Atelektazi, mekanik ventilator, yenidoğan, rhDNaz.

Fatma Duksal

Yazışma Adresi:Cumhuriyet Üniversitesi, Tıp Fakültesi, Çocuk Sağlığı ve Hastalıkları AD, Çocuk Alerji ve İmmünoloji BD, Sivas

e-mail: fatmaduksal@gmail.com

Gönderilme tarihi: 05.11.2013

Kabul tarihi: 10.01.2014 


\section{Introduction}

In respiratory distress syndrome (RDS), due to surfactant deficiency, there was a mismatching in ventilation-perfusion. Hyaline membranes and inflammation in RDS blocks small airways, causing atelectasis and over inflation [1]. Inflammation causes necrosis of epithelial cell and thick mucous production in respiratory system, leading occlusion of airway lumen [2]. This occlusion may be partial leading to air trapping and hyperinflation. But total occlusion causes atelectasis [3]. Lysis of inflammatory cells, mostly leucocytes, leads to large amount of deoxyribonucleic acid (DNA) production in mucous plugs [4,5]. Recombinant human deoxyribonuclease (rhDNase) extensively reduces the viscosity of mucous, transforming it from a viscous gel to a flowing liquid within minutes by hydrolysing extracellular DNA in mucous [6,7]. Inhalated form of rhDNase with nebulizer, has been well studied in cystic fibrosis (CF) [4-8]. Other than $\mathrm{CF}$, in some studies rhDNase has been found effective in the treatment of respiratory syncytial virus bronchiolitis [3,9]. In addition, it was found effective in atelectasis of ventilated neonates $[2,10]$ There has been limited data in premature newborn for the efficacy of rhDNase.

The aims of this study were to see the efficacy in atelectasis and clinical and radiological effectiveness of rhDNase in RDS newborns unresponsive to conventional therapy.

\section{Material and Methods Patients}

Eight newborns (7 premature) with atelectasis in different parts of the lungs were participated in to the study. These patients had been already taken frequent aspiration, positioning, chest physiotherapy, endotracheal aspiration, medical treatment with $\mathrm{N}$-acetylcysteine, $3 \%$ $\mathrm{NaCL}$ and salbutamol with nebulizer. rhDNase was given to all patients after these therapies. In addition, one patient received 3 times and the other patients received 2 times of surfactant with a dosage of $200 \mathrm{mg} / \mathrm{kg}$ [11] among the prematures.

The rhDNase treatment was explained to the parents and they signed a consent form in order to participate to the study. rhDNase was administered as a part of the medical treatment of the patients. However, this treatment was not for the research. Because of this, approval from ethic committee was not needed.

\section{Treatment}

rhDNase (Germany Pulmosyme, Roche, Genentech Inc, San Farncisco, CA, USA) was given to patients two times in a day (12 hours period) for 3 days with an amount of $2.5 \mathrm{mg}$ each with nebulizer. The treatment protocol was based on previous study [3]. The outcomes of the treatment were retrospectively analyzed. Clinically, lung examination, respiration rate, oxygen needs for the patients and whether the patients were extubated or not were evaluated. Radiologic evaluation to all patients was made with chest radiograph. At their chest radiograph, partial or total atelectasis was evaluated.

The administration of rhDNase was associated especially with alteration in voice (e.g; hoarseness), pharyngitis and laryngitis. In addition, it was associated with rash, chest pain, and conjunctivitis. But no anaphylaxis was reported during rhDNase treatment [12]. The patients were observed for the possible side effects of rhDNase.

\section{Results}

Demographic and treatment characteristics of patients are shown in Table 1. Male \& female ratio was $5 / 3$ (1.66). Seven of 8 patients were premature newborns. The other patient, who was born in time, had diagnosis of hypoxic ischemic encephalopathy (HIE). The birth weight and gestational age of the patients ranged respectively from $500 \mathrm{~g}$ to $3000 \mathrm{~g}$ and 25 weeks to 41 weeks. When atelectasis developed, six of eight patients were mechanically ventilated. Our infants received a dosage of $2.5 \mathrm{mg}$ rhDNase every 12 hours with nebulizer for 3 days. Mechanically ventilated patients received rhDNase by an apparatus connected to circulation of mechanical ventilator. Six of 8 patients showed almost complete improvement after the rhDNase treatment (Figure 1 and Figure 2). One patient ( $4^{\text {th }}$ patient) who did not respond to the treatment had already an underlying HIE and complicated pneumonia in addition to being unresponsive to medical treatment. This patient died during the follow up. Other patient $\left(3^{\text {rd }}\right.$ patient) gave partial response to treatment and general improvement was seen in aeration. Of 6 mechanically ventilated patients, 3 patients 
Tablo 1. Demographic and treatment characteristic of patients

\begin{tabular}{ll}
\hline Gestational week (median, range) & $29.4(24-41)$ \\
Premature/mature & $7 / 1$ \\
Birth weight (median, range)(grams) & $1375(500-3000)$ \\
Male/female & $5 / 3$ \\
Mechanically ventilation/no ventilation & $6 / 2$ \\
Age during rhDNase treatment (median, range) (days) & $35.6(13-70)$ \\
Duration of rhDNase treatment (median, range) (days) & $3(3)$ \\
\hline
\end{tabular}

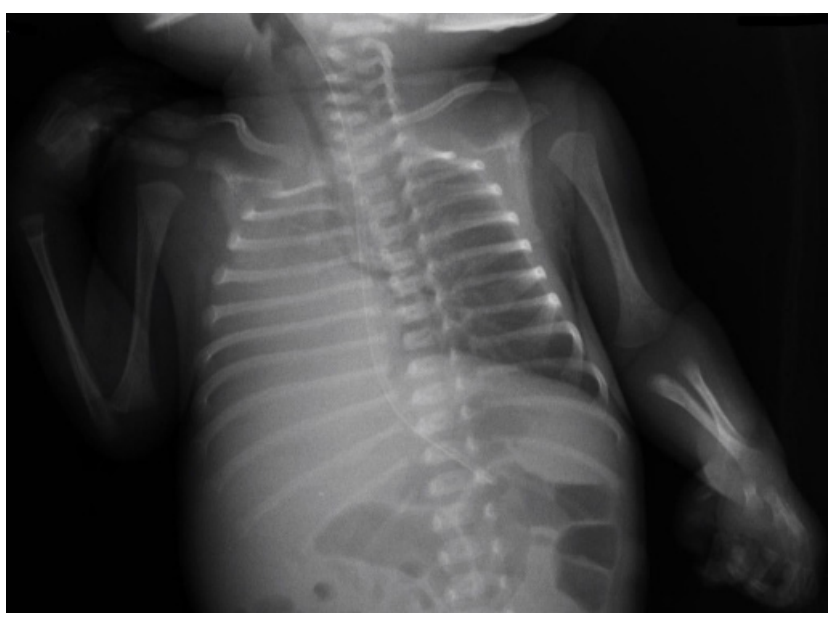

Figure 1. Right side total atelectasis in $8^{\text {th }}$ patient.

extubated in 3 days, one patient extubated after 9 days and 2 patients could not be extubated. Atelectasis relapsed in 6 patients. After second 3-day course of treatment by a nebulizer, recovery was seen in 3 days. And rhDNase was continued to these patients for 1 month. Five patients that had taken recurrent rhDNase treatment were reevaluated after 1 month of the treatment. Decrease at respiratory rate and oxygen need was seen in one patient. In this patient, in spite of not showing any development of new atelectasis, extubation could not be made. Respiratory rate and lung examination of other patients were normal and there was no new atelectasis. Characterization of atelectasis and treatment of patients are shown in table 2 . The patients were evaluated for the possible side effects of rhDNase. But we didn't see any side effect resulted from rhDNase treatment during the study period.

\section{Discussion}

rhDNase (Dornase alfa), a recombinant enzyme, is a mucokinetic agent that degrades extracellular DNA. It can increase the clearance of mucous by increasing the effectiveness of cough, and by the thick secretions from

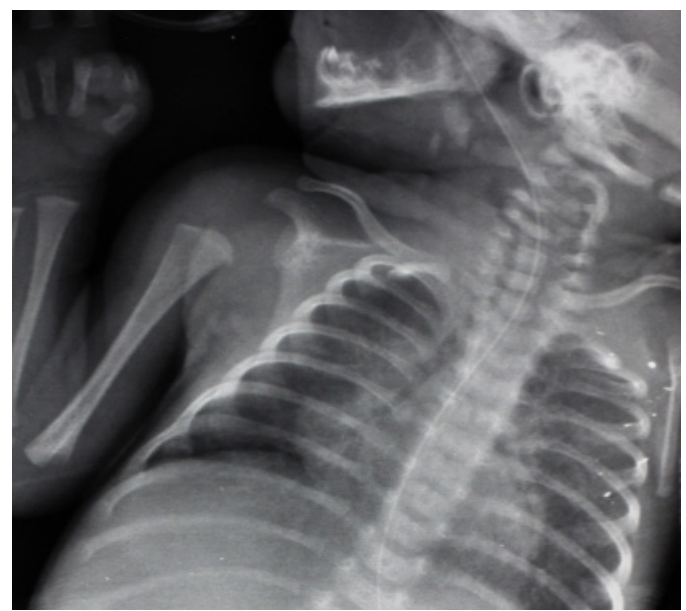

Figure 2. Improvement of atelectasis in 3 days after rhDNase by nebulizer.

the airway walls [13]. It has been already well known and used for nearly 20 years and generally used in the treatment of patients with CF. In CF, it increases mucous clearance and regulates inflammatory process in the airway [14-16]. It was suggested that, apart from CF, rhDNase could be used in the management of pneumonia and mechanically ventilated patients with atelectasis unresponsive to conventional treatments [16].

In our study, 8 patients were analyzed retrospectively. At the study, 6 of 8 patients showed almost complete improvement after the rhDNase treatment and 4 patients recovered from the mechanical ventilation. Third patient gave partial response to treatment and general improvement in aeration was seen. This may be due to the underlying complicating pneumonia in this patient; because, rhDNase degrades the thick secretions from the airway and so increases the clearance of mucous. But it may not be effective for the treatment of the infection as clearance of mucous. In our study, atelectasis relapsed in 6 patients. We did not give rhDNase endotracheally as second regimen treatment. But rhDNase was administered to 5 of these 6 patients by a nebulizer and recovery was seen 
Tablo 2. Diagnosis, characterization of atelectasis and treatment of patients

\begin{tabular}{|c|c|c|c|c|c|c|c|c|}
\hline Patients & Diagnosis & $\begin{array}{l}\text { Localization } \\
\text { of atelectasis }\end{array}$ & $\begin{array}{l}\text { Mechanical } \\
\text { ventilation }\end{array}$ & $\begin{array}{l}\text { Postnatal age } \\
\text { at rhDNase } \\
\text { treatment } \\
\text { (day) }\end{array}$ & $\begin{array}{l}\text { Duration of } \\
\text { rhDNase } \\
\text { treatment } \\
\text { (day) }\end{array}$ & $\begin{array}{l}\text { Extubation of } \\
\text { patients after } \\
\text { rhDNase } \\
\text { treatment } \\
\text { (day) }\end{array}$ & $\begin{array}{l}\text { Recurrent } \\
\text { atelectasis }\end{array}$ & $\begin{array}{c}\text { Repeated } \\
\text { rhDNase } \\
\text { treatment }\end{array}$ \\
\hline $1^{\text {st }}$ patient & RDS, BPD & RUL & NO & 47 & 3 & - & NO & NO \\
\hline $2^{\text {nd }}$ patient & RDS, BPD & RUL & YES & 26 & 3 & Not extubated & YES & YES \\
\hline $3^{\text {rd }}$ patient & $\begin{array}{l}\text { RDS, BPD, } \\
\text { pneumonia }\end{array}$ & RLL, LLL & YES & 44 & 3 & 3 & YES & YES \\
\hline $4^{\text {th }}$ patient & $\begin{array}{c}\text { HIE, } \\
\text { pneumonia }\end{array}$ & RUL & YES & 36 & 3 & Not extubated & YES & NO \\
\hline $5^{\text {th }}$ patient & RDS, BPD & RUL & YES & 13 & 3 & 2 & YES & YES \\
\hline $6^{\text {th }}$ patient & RDS & $\begin{array}{l}\text { Total right } \\
\text { lung }\end{array}$ & YES & 21 & 3 & 9 & YES & YES \\
\hline $7^{\text {th }}$ patient & $\begin{array}{c}\text { RDS, } \\
\text { esophageal } \\
\text { atresia RDS }\end{array}$ & RUL & YES & 70 & 3 & 3 & YES & YES \\
\hline $8^{\text {th }}$ patient & RDS, ASD & $\begin{array}{l}\text { Total right } \\
\text { lung }\end{array}$ & NO & 28 & 3 & - & NO & NO \\
\hline
\end{tabular}

ASD:atrial septal defect; RDS: respiratory distress syndrome; BPD: bronchopulmonary dsplasia; HIE: hypoxic ischemic encephalopathy; RUL: right upper lung; RLL: right lower lung, LLL: left lower lung

in 3 days. Because patient with HIE did not benefit from medication with rhDNase, it was not administered again to this patient. rhDNase was continued to other patients for 1 month against the possibility of re-occurrence of atelectasis. After 1 month, patients were evaluated and none of them had new atelectasis.

In one study, atelectasis developed after severe RSV bronchiolits in 5 infants [3]. rhDNase with nebulizer ( $2.5 \mathrm{mg}$ twice daily) was administered to these infants for two days and after administration of rhDNase, all infants showed clinical and radiological improvement after the first dose of rhDNase. Two patients recovered from ventilation after the treatment, while 3 other patients showed dramatic improvement. In the study of Fedakar et al [17], 12 prematures and 10 term newborns received rhDNase with a dose of $1 \mathrm{mg} / \mathrm{m} 2$ twice daily for 3 days. They observed a clinical and radiologic improvement of atelectasis in 18 patients. Endotracheal and nebulized rhDNase treatment was administered to 4 patients in whom atelectasis was relapsed. Improvement of atelectasis was reported in these patients also. They did not see any side effects due to treatment like our study. Erdeve et al [2], gave nebulized rhDNase therapy at a dose of $1.25 \mathrm{mg}$ over a 15-minute period, twice a day ( 2 hours between the doses) for up to 3 days to newborns (10 preterms), who did not respond to conventional methods. Two patients who did not respond to this treatment received an additional single dose of the rhDNase endotracheally and showed clinical and radiological improvement. In our study, two patients did not mechanically ventilated and had complete recovery for atelectasis after treatment. Of 6 mechanically ventilated patients 4 patients recovered from the mechanical ventilation. One patient gave partial response to treatment and general improvement in aeration was seen. In our study, atelectasis relapsed in 6 patients. In the study of Fedakar et al [17] and Erdeve et al [2], rhDNase was administered endotracheally in the second regimen. But, we gave rhDNase with nebulizer again to 5 of these 6 patients. And recovery was seen in 3 days. rhDNase was continued to these patients for 1 month against the possibility of re-occurrence of atelectasis. After 1 month, patients were evaluated and none of the patients had new atelectasis. El Hassan et al [18] also reported the effectiveness of rhDNase in 3 premature infants like our study.

Riethmueller et al. [19] reported that in infants who received rhDNase the incidence of atelectasis, median ventilation time and median length of stay in intensive care unit were lower than placebo group, but re-intubation rates did not change. In our study six of 8 patients showed almost complete improvement after the rhDNase treatment. In addition, of 6 
mechanically ventilated patients, 4 patients could be extubated.

According to results of our study, seven patients had beneficial effect from rhDNase treatment, especially if there was not any underlying disease. Voice alteration and rash were reported as the mild side effects of rhDNase in CF patients [20]. In addition, the administration of rhDNase was associated with alteration in pharyngitis, laryngitis, chest pain, and conjunctivitis [12]. But in our study, rhDNase was administered to patients with no clear side effect.

In a study, no statistical difference was found between hypertonic saline, normal saline, and dornase alpha in the treatment of atelectasis [21]. However, in our study, all patients were already taken hypertonic saline treatment which is a part of traditional treatment and their atelectasis did not get better via this treatment. During hypertonic saline treatment, rhDNase treatment was also begun. Hence, comparison could not be made.

Limitations of the study: Comparison should be made with hypertonic saline treatment. But, when rhDNase treatment was begun, the patients were already taken hypertonic saline treatment. So we couldn't compare them with each other. In addition, long term following of the patients is also important in terms of finding out side effects. Another issue can be thought as the insufficient number of the patients; so, working with more patients and control group are needed in order to provide more successful outcomes in this work. Moreover, if the patients could be followed prospectively rather than retrospectively, the possible adverse effect could be determined easier.

We suggest that rhDNase may be administered as an alternative treatment to the newborn infants with atelectasis in their lung; especially, if there was not any underlying disease and if they did not respond to conventional treatment for atelectasis.

Conflict of interest: The authors declared no conflict of interest.

\section{References}

1. Ainsworth SB. Pathophysiology of neonatal respiratory distress syndrome: implications for early treatment strategies. Treat Respir Med 2005;4:423-437.

2. Erdeve O, Uras N, Atasay B, Arsan S. Efficacy and safety of nebulized recombinant human DNase as rescue treatment for persistent atelectasis in newborns: case-series. Croat Med J 2007;48:234-239.

3. Merkus PJ, de Hoog M, van Gent R, de Jongste JC. DNase treatment for atelectasis in infants with severe respiratory syncytial virus bronchiolitis. Eur Respir J 2001;18:734-737.

4. Armstrong JAB, White JC. Liquefaction of viscous purulent exudates by deoxyribonuclease. Lancet 1950;2:739-742.

5. Potter JL, Spector S, Matthew LW, Lemm J. Studies on pulmonary secretions. 3 . The nucleic acids in whole pulmonary secretions from patients with cystic fibrosis, bronchiectasis, and laryngectomy. Am Rev Respir Dis 1969;9:909-916.

6. Fitzgerald DA, Hilton J, Jepson B, Smith L. A crossover, randomized, controlled trial of dornase alfa before versus after physiotherapy in cystic fibrosis. Pediatrics 2005;116:e549-554.

7. Shak S, Capon DJ, Hellmiss R, Marsters SA, Baker $\mathrm{CL}$. Recombinant human DNase I reduces the viscosity of cystic fibrosis sputum. Proc Natl Acad Sci 1990;87:9188-9192.

8. Hubbard RC, McElvany NG, Birrer P, et al. A preliminary study of aerosolized human deoxyribonuclease $\mathrm{I}$ in the treatment of cystic fibrosis. N Engl J Med 1992; 326: 812-815.

9. Nasr SZ, Strouse PJ, Soskolne E, et al. Efficacy of recombinant human deoxyribonuclease $\mathrm{I}$ in the hospital management of respiratory syncytial virus bronchiolitis. Chest 2001;120:203-208.

10. MacKinnon R, Wheeler KI, Sokol J. Endotracheal DNase for atelectasis in ventilated neonates. J Perinatol 2011;31:799-801.

11. Tsakalidis C, Kourti M, Karagianni P, Rallis D, Porpodi M, Nikolaidis N. Early rescue administration of surfactant and nasal continuous positive airway pressure in preterm infants $<32$ weeks gestation. Indian Pediatr 2011;48:601-605.

12. Fuchs HJ, Borowitz DS, Christiansen DH, et al. The Pulmozyme Study Group. Effect of aerosolized recombinant human DNase on exacerbations of respiratory symptoms and on pulmonary function in patients with cystic fibrosis. $\mathrm{N}$ Engl $\mathrm{J}$ Med 1994;331:637-642.

13. Rubin BK. Mucolytics, expectorants, and mucokinetic medications. Respir Care 2007;52:859-865.

14. Hodson ME, McKenzie S, Harms HK,et al. Dornase alfa in the treatment of cystic fibrosis in Europe: a report from the epidemiologic registry of cystic fibrosis. Paediatric Pulmonology 2003;36:427-432. 
15. Paul K, Rietschel E, Ballmann M, et al. Effect of treatment with dornase alfa on airway inflammation in patients with cystic fibrosis. Am J Respir Crit Care Med 2004;169:719-725.

16. Wagener JS, Kupfer O. Dornase alfa (Pulmozyme). Curr Opin Pulm Med 2012;18:609-614.

17. Fedakar A, Aydogdu C, Fedakar A, Ugurlucan M, Bolu S, Iskender M. Safety of recombinant human deoxyribonuclease as a rescue treatment for persistent atelectasis in newborns. Ann Saudi Med 2012;32: 131-136.

18. El Hassan NO, Chess PR, Huysman MW, Merkus $\mathrm{PJ}$, de Jongste JC. Rescue use of DNase in critical lung atelectasis and mucus retention in premature neonates. Pediatrics 2001;108:468-470.
19. Riethmueller J, Borth-Bruhns T, Kumpf $M$, et al. Recombinant human deoxyribonuclease shortens ventilation time in young, mechanically ventilated children. Pediatr Pulmonol 2006;41:61-66.

20. Jones AP, Wallis C. Dornase alfa for cystic fibrosis. Cochrane Database Syst Rev 2010 Mar 17;(3):CD001127. doi: 10.1002/14651858.

21. Youness HA, Mathews K, Elya MK, Kinasewitz GT, Keddissi Jl. Dornase alpha compared to hypertonic saline for lung atelectasis in critically ill patients. J Aerosol Med Pulm Drug Deliv. 2012;25:342-348. 